\title{
Hypophosphatemia and risk of refeeding syndrome in critically ill patients before and after nutritional therapy
}

\author{
D Amanda Coelho Ribeiro' \\ Diana Borges Dock-Nascimento ${ }^{2}$ \\ (D) João Manoel Silva Jr. , $^{3,6}$ \\ (iD) Cervantes Caporossi ${ }^{4}$ \\ (iD) José Eduardo de Aguilar-Nascimento ${ }^{4,5}$
}

1. Nutricionista, Mestre em Ciências da Saúde pelo Programa de Pós-Graduação em Ciências da Saúde da Universidade Federal de Mato Grosso, Cuiabá, MT, Brasil 2. Nutricionista, Professor Doutor Associado II, Faculdade de Nutrição da UFMT, Departamento de Alimentos e Nutrição em Cuiabá-MT. Professor orientador do Programa de Pós-Graduação em Ciências da Saúde da Universidade Federal de Mato Grosso, Cuiabá, MT, Brasil 3. Médico, Professor orientador do Programa de Pós-Graduação em Anestesiologia da Universidade de São Paulo, São Paulo, SP, Brasil 4. Médico, Professor Doutor do Programa de Pós-Graduação em Ciências da Saúde da Universidade Federal de Mato Grosso, Cuiabá, MT, Brasil 5. Diretor do Curso de Medicina do Centro Universitário de Várzea Grande (Univag), Várzea Grande, MT, Brasil 6. Componente do corpo clínico do Hospital Israelita Albert Einstein, São Paulo, SP, Brasil

SUMMARY

OBJECTIVE: To investigate the prevalence of hypophosphatemia as a marker of refeeding syndrome (RFS) before and after the start of nutritional therapy (NT) in critically ill patients.

METHODS: Retrospective cohort study including 917 adult patients admitted at the intensive care unit (ICU) of a tertiary hospital in Cuiabá-MT/Brasil. We assessed the frequency of hypophosphatemia (phosphorus $<2.5 \mathrm{mg} / \mathrm{dl}$ ) as a risk marker for RFS. Serum phosphorus levels were measured and compared at admission (P1) and after the start of NT (P2).

RESULTS: We observed a significant increase (36.3\%) of hypophosphatemia and, consequently, a greater risk of RFS from P1 to P2 (25.6 vs 34.9\%; $p$ 0.001). After the start of NT, malnourished patients had a greater fall of serum phosphorus. Patients receiving NT had an approximately 1.5 times greater risk of developing RFS (OR=1.44 95\% Cl 1.10-1,89; $p=0.01)$ when compared to those who received an oral diet. Parenteral nutrition was more associated with hypophosphatemia than either enteral nutrition ( $p=0,001)$ or parenteral nutrition supplemented with enteral nutrition $(p=0,002)$.

CONCLUSION: The frequency of critically ill patients with hypophosphatemia and at risk for RFS on admission is high and this risk increases after the start of NT, especially in malnourished patients and those receiving parenteral nutrition.

KEYWORDS: Critical care; Hypophosphatemia; Refeeding Syndrome; Malnourished; Nutritional Therapy.

\section{INTRODUCTION}

Hypophosphatemia is recognized as a marker of refeeding syndrome (RFS) ${ }^{1.2}$. This change in the levels of phosphorus is more frequent among malnourished patients, in starvation, or among those with low calory intake ${ }^{1.2}$.

A recent study showed that RFS occurred in $36.8 \%$

DATE OF SUBMISSION: 24-Jan-2020

DATE OF ACCEPTANCE: 26-Feb-2020

CORRESPONDING AUTHOR: José Eduardo de Aguilar Siqueira do Nascimento

Rodovia Arquiteto Helder Cândia, 2755, Condomínio Residencial Country casa 15, Bairro Ribeirão do Lipa, CEP 78048-150,

Cuiabá, MT, Brasil. Tel.: 65-9 9981-5388

Email: aguilar@terra.com.br. 
of the 337 patients in an intensive care unit (ICU), 72 hours after nutritional therapy (NT) was started ${ }^{3}$. In this study, hypophosphatemia was used to diagnose $\mathrm{RFS}^{3}$. For this reason, it is essential to correct the phosphorus level; the low serum value often goes undiagnosed or remains uncorrected on admission ${ }^{4}$. In this sense, studies show that $15 \%$ to $52 \%$ of the patients are hospitalized with hypophosphatemia ${ }^{4-8}$.

This reduction of serum phosphorus, in the initial phase of NT, causes a rapid change in phosphorus from intravascular to intracellular, resulting in hypophosphatemia ${ }^{1.2}$. RFS usually begins on the third day after NT is started ${ }^{3,9,10}$ and hypophosphatemia is a risk factor for its development ${ }^{1-3,10-12}$. For this reason, some authors started referring to RFS as hypophosphatemia syndrome or refeeding hypophosphatemia ${ }^{6,12,13}$. Phosphorus must be monitored to detect refeeding hypophosphatemia and, when it occurs, a caloric restriction must be instituted, with at least $1.3 \mathrm{~g}$ of protein $/ \mathrm{kg} /$ day in the initial phase of refeeding ${ }^{14}$.

In the Brazilian literature, we found review articles on the subject ${ }^{15}$ and a single case report ${ }^{16}$, but we did not find studies with data collected in Brasil. In this sense, it would be interesting to determine the frequency of hypophosphatemia in a national ICU, since this event is used as a marker of RFS in critical adult patients. Thus, the present study aimed to determine the presence of hypophosphatemia as a marker of RFS before and after the start of NT in intensive care patients.

\section{METHODS}

A retrospective cohort study performed with adult patients in the ICU of a tertiary hospital in Cuiabá-MT. The data collected from the medical charts refer to the period from 06/2014 to $12 / 2016$. The study was approved by the Research Ethics Committee under CAAE: 47021715.0.0000.5541/2015 and is compliant with Resolution 196/96 of the National Health Council.

All patients admitted to the ICU, with age $\geq 18$ years, of both sexes, and who had results of at least two examinations of serum phosphorus in the first week were considered eligible. The main variables were the phosphorus values on admission (P1) and after the start of NT (P2) and the association of hypophosphatemia with NT and nutritional status. The presence of hypophosphatemia (serum phosphorus $<2.5 \mathrm{mg} / \mathrm{dl}$ ) was defined as a risk marker for RFS on $\mathrm{P} 1$ and $\mathrm{P} 2^{3,5,7,8,13}$.
We collected data on patients' demographic, treatment (clinical or surgical), diet received (oral, enteral NT, parenteral or mixed NT [NT associated with oral or parenteral NT]), nutritional state, hospitalization time (days), and mortality. The inflammatory profile was established by PCR/serum albumin measured in the first 48 hours after hospitalization. The nutritional assessment was carried out by subjective global assessment (SGA) $)^{17}$.

NT was initiated within the first 48 hours, in the presence of hemodynamic stability. Enteral NT, when prescribed, was initiated after confirming the tube location by X-ray. The nutritional needs were prescribed according to a routine published by our group, i.e., 25 to $30 \mathrm{kcal} / \mathrm{kg}$ and 1.25 to $2.0 \mathrm{~g}$ of protein $/ \mathrm{kg}$ of body weight ${ }^{18}$. In the presence of hypophosphatemia, the replacement of serum phosphorus was established according to the value found ${ }^{19}$. For mild hypophosphatemia (2.3 to $3 \mathrm{mg} / \mathrm{dl}$ ), there was a replacement of $0.16 \mathrm{mEq} / \mathrm{kg}$ at 4 and 6 hours; for moderate hypophosphatemia (1.6 to $2.2 \mathrm{mg} / \mathrm{dl}$ ), of $0.32 \mathrm{mEq} / \mathrm{kg}$ at 4 and 6 hours; and for severe hypophosphatemia $(<1.5$ $\mathrm{mg} / \mathrm{dl})$, of $0.64 \mathrm{mEq} / \mathrm{kg}$ at 8 and 12 hours $^{19}$.

\section{Statistical analysis}

We used the chi-square test to analyze the categorical variables. The continuous variables were initially analyzed by the Levene test to verify their homogeneity, followed by the Kolmogorov-Smirnov test to determine their normality. The chi-square test for trend with Yates correction was used to evaluate the difference between hypophosphatemia at P1 and P2. The paired t-test was used to compare the mean values of P1 and P2. The data were expressed as numbers and percentages or mean and standard deviation. The odds ratio (OR) and a 95\% confidence interval were used for comparisons of RFS and hypophosphatemia risk. We established a limit of statistical significance of 5\% $(p \leq 0.05)$. The statistical analysis was carried out using the SPSS statistical package for the Social Sciences 20.0 (SPSS Statistics; IBM, Armonk, NY, USA).

\section{RESULTS}

There were 1,302 eligible patients, of which 387 were excluded for not having the results of the first $(\mathrm{n}=2)$ and second $(\mathrm{n}=385)$ sample of serum phosphorus. We included in the study 917 patients with a mean age of $62.9 \pm 17.6$ years, of which 464 (50.6\%) were males. Of these, $576(62.8 \%)$ were hospitalized 
for clinical treatment, and 341 (37.2\%) for surgical treatment.

Regarding their nutritional state, 13.3\% ( $\mathrm{n}=122)$ were eutrophic, $66.2 \%(\mathrm{n}=607)$ were at risk of malnutrition or had moderate malnutrition, and 20.5\% ( $\mathrm{n}=188$ ) had severe malnutrition. After 48 hours of hospitalization, $521(56.8 \%)$ patients received some kind of NT (Figure 1). Thus, 329 (63.1\%) received enteral nutrition, 43 (8.3\%) received parenteral nutrition, and 149 (28.6\%) received enteral nutrition supplemented with parenteral nutrition. The mean hospitalization time was $11.7 \pm 14.9$ days and the mortality rate was $30.6 \%$ $(\mathrm{n}=202)$. The mean serum albumin was $2.93 \pm 0,57 \mathrm{~g} / \mathrm{dL}$, the PCR was $104.2 \pm 92.0 \mathrm{mg} / \mathrm{dL}$, and the PCR/albumin ratio was $42.7 \pm 40.3$.

Hypophosphatemia and, consequently, the risk of RFS were identified in $25.6 \%(\mathrm{n}=235)$ and $34.9 \%(\mathrm{n}=320)$ of the cases, respectively at P1 and P2 ( $<<0.001)$. There was a $36.3 \%$ increase in the incidence of hypophosphatemia throughout the period studied (Figure 2). Table 1 shows that the mean phosphorus values on the second collection were lower than those on the first $(p=0.004)$. However, this significant difference was not maintained when comparing only patients admitted with hypophosphatemia $(\mathrm{p}=0.194)$.

The patients who received NT had more chance of developing hypophosphatemia and a greater risk of RFS in P2 (OR=1.44, 95\% CI, 1.1-1.89; $\mathrm{p}=0.01)$ when compared to those who received an oral diet. Patients who received parenteral nutrition (27/43; $62.8 \%$ ) had more chances of hypophosphatemia when compared with the group that received enteral nutrition (124/329, 37.7\%; OR=2.79 - 95\% CI: 1.44$5.38 ; \mathrm{p}=0.001)$ and with those who received enteral nutrition supplemented with parenteral nutrition (56/149, 37.6\%; OR=2.80 - 95\% CI: 1.39-5.65; $\mathrm{p}=0.002)$. The malnourished patients showed a tendency to develop more hypophosphatemia $(p=0.051)$ in P2 than non-malnourished ones. However, the

TABLE 1. SERUM PHOSPHORUS OF THE PATIENTS STUDIED.

\begin{tabular}{|c|c|}
\hline Variables & Mean \pm SD \\
\hline Value at P1 (mg/dl) & $3.33 \pm 1.3^{*}$ \\
\hline Value at P2 (mg/dl) & $3.18 \pm 1.57$ \\
\hline Value at P1 for hypophosphatemia (mg/dl) & $1.87 \pm 0.42$ \\
\hline Value at P2 for hypophosphatemia (mg/dl) & $1.91 \pm 0.43$ \\
\hline
\end{tabular}

mean serum phosphorus in P2 (nourished: $3.42 \pm 1.68$ vs malnourished: $3.14 \pm 1.55 \mathrm{mg} / \mathrm{dl} ; \mathrm{p}=0.04$ ) was significantly lower among the malnourished patients. On admission, i.e., at P1 (nourished: $3.49 \pm 1.37 v s$ malnourished: $3.31 \pm 1.29 \mathrm{mg} / \mathrm{dl} ; \mathrm{p}=0.22$ ), there was no difference.

\section{DISCUSSION}

Our results show that approximately $25 \%$ of critical patients were hospitalized with hypophosphatemia and, therefore, with a risk of RFS. In addition, there was an increase of approximately $36 \%$ in cases of patients with hypophosphatemia when the second collection of phosphorus was analyzed. In other words, after the start of NT, little more than $1 / 3$ of the patients presented hypophosphatemia. This means that patients undergoing NT had nearly 1.5 more chances of developing hypophosphatemia and, consequently, the risk of RFS. Other studies have shown

\section{FIGURE 1. TYPE OF DIET RECEIVED BY THE PATIENTS} STUDIED.

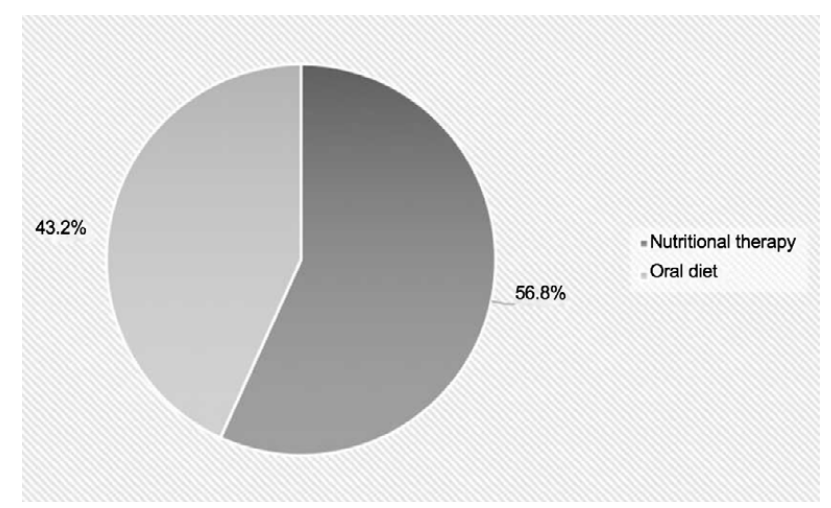

FIGURE 2. DISTRIBUTION OF THE

HYPOPHOSPHATEMIA FREQUENCY AND RISK OF REFEEDING SYNDROME FOR PHOSPHORUS 1 (P1) AND PHOSPHORUS $2(P 2)^{*} P<0.001$ VS HYPOPHOSPHATEMIA (P1). CHI-SQUARED TEST FOR TREND WITH YATES' CORRECTION.

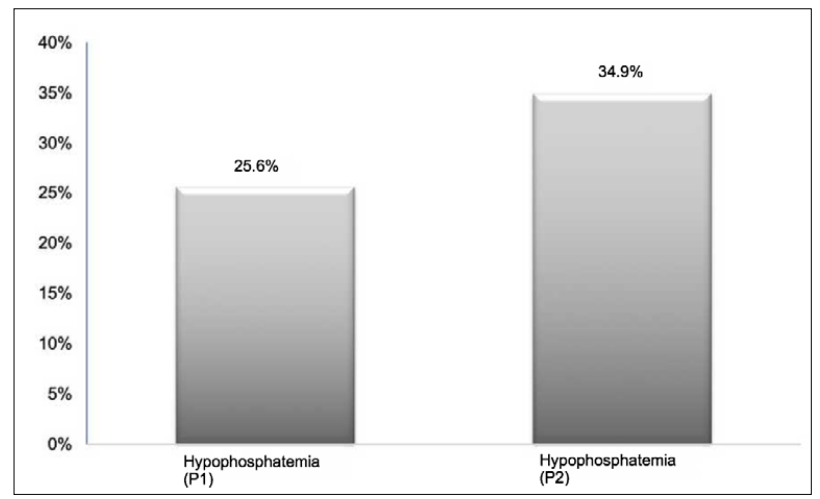


an occurrence of hypophosphatemia in intensive care patients similar to our findings and this abnormality is common and undiagnosed after the start of $\mathrm{NT}^{3-6}$. Another important point is that hypophosphatemia is used as a parameter for the diagnosis of RFS or "hypophosphatemia syndrome"13.20.

Unfortunately, there is no universally accepted definition for diagnosing RFS with unambiguous criteria $^{21}$. However, a systematic review has shown that hypophosphatemia is present in more than $95 \%$ of documented cases of RFS and that this phosphatemia is commonly used, in clinical practice, as a marker of RFS ${ }^{1,3,10,13}$. It is important to highlight that RFS, diagnosed pragmatically based on hypophosphatemia, is induced by refeeding, particularly when this is carried out in full during the first three days of $\mathrm{NT}^{1,3,7,9,10}$. Therefore, soon after admission and mainly in the second or third day of nutrition, it is fundamental to monitor phosphorus values to prevent RFS $^{1,10,11,13,14,17,19,21}$.

Our data show that not only $1 / 4$ of critical patients are already admitted with hypophosphatemia, but also that this abnormality increases after the start of NT when compared to patients who received an oral diet. Although we do not have numerical data on the calories and proteins offered, one may speculate that these patients undergoing NT received more calories and nutrients than the patients who received an oral diet. This may have contributed greatly to the greater decrease in serum phosphorus values in the NT group ${ }^{1,2,3,17}$.

Although there was no significant difference, the number of patients with malnutrition showed a tendency of developing hypophosphatemia after the start of the diet when compared to nourished patients. However, serum phosphorus values showed that, on average, they were significantly lower in malnourished patients. Indeed, early diagnosis of the nutritional state helps the team to identify patients at risk of RFS who can benefit from a slower and more restricted supply of calories ${ }^{11,12,14}$. Our data are similar to those of the literature and show that malnourished patients are more prone to developing hypophosphatemia with the start of NT.

In the light of these results, although there was an intervention to correct the phosphorus levels, it seems to have been ineffective and, therefore, it is pertinent to monitor the serum phosphorus levels in critical patients before and after the start of NT. These patients should receive NT with a reduced supply of calories while the correction of electrolytes, especially of phosphorus, is carried out ${ }^{1,8,11,14,17}$.

It should be remembered that unlike in an oral diet, in which the patient must voluntarily ingest foods, with parenteral or enteral NT the supply does not depend on their will. Thus, this invasive supply of calories may have contributed both to the drop of phosphorus values and to the increase in hypophosphatemia when the second collection of phosphorus was analyzed. In this regard, our data show that patients who received parenteral nutrition alone presented a higher risk of developing hypophosphatemia than those who received enteral nutrition alone or associated with parenteral nutrition. Indeed, the literature shows that hypophosphatemia has been more associated with parenteral nutrition ${ }^{1}$, but it is interesting to note that this can also occur in patients receiving enteral nutrition ${ }^{13}$.

Another important point is that in the initial phase of the inflammatory and neurohormonal response there is an accelerated muscle protein catabolism with the production of approximately 1,200 kcal/day ${ }^{22}$. Thus, it is vital to acknowledge this endogenous production of calories to avoid excess feeding and unfavorable outcomes, such as RFS ${ }^{23}$.

In this context, Nice ${ }^{11}$ recommends starting NT with less than $50 \%$ of the target caloric intake for patients with a risk of RFS. For some, it is recommended to start with 5 to 10 calories per kilogram of body weight associated with monitoring of blood glucose levels and the correction of phosphorus, magnesium, potassium, and thiamine levels ${ }^{1,12,15}$.

Although the present study adds interesting data to the literature, it has limitations, such as the lack of the number of calories and proteins offered to patients. This would have enabled a better analysis of the results. Another limitation is the lack of a severity score; however, some studies have used the PCR/albumin ratio as an important marker of inflammation, prognosis, and mortality ${ }^{24}$.

\section{CONCLUSION}

The prevalence of critical patients with hypophosphatemia and a consequent risk of RFS is high. This risk increases after the start of NT, especially in malnourished patients and those who receive parenteral nutrition alone. Thus, it is important to monitor the serum phosphorus during hospitalization and in the days following the start of NT. 


\section{Institution}

Programa de Pós-Graduação em Ciências da Saúde, da Faculdade Medicina da Universidade Federal de Mato Grosso, Avenida Fernando Correa da Costa, s/n, Cuiabá, MT, Brasil.

\section{Author's Contribution}

Amanda Coelho Ribeiro: Participated in the investigation, methodology, resource, and drafting.
Diana Borges Dock-Nascimento: Participated in the conceptualization, data analysis, methodology, resource, supervision, drafting, revision, and editing.

João Manoel Silva Jr: Methodology and drafting, revision, and editing.

Cervantes Caporossi: Formal analysis, methodology, and drafting.

José Eduardo de Aguilar-Nascimento: Formal analysis, methodology and drafting, revision, and editing.

\section{RESUMO}

OBJETIVO: Determinar a frequência de hipofosfatemia como marcador da síndrome de realimentação (SR) antes e após o início da TN em pacientes críticos.

MÉTODOS: Coorte retrospectiva realizada com 917 pacientes adultos de um hospital terciário em Cuiabá-MT. Foi determinada a frequência de hipofosfatemia (fósforo <2,5 mg/dl) como marcador de risco de SR, para valores de fósforo sérico da admissão (P1) e após o início da TN (P2).

RESULTADOS: Foi observado um aumento significativo (36,3\%) da hipofosfatemia entre P1 e P2 e, consequentemente, do risco de SR (25,6\% vs 34,9\%; p<0,001) com o início da TN. Após o início da TN, pacientes desnutridos apresentaram maior queda do fósforo sérico. Os pacientes com TN apresentaram aproximadamente 1,5 vez mais chance de desenvolver hipofosfatemia e risco de $S R$ (OR=1,44 IC95\% 1,10-1,89; $p=0,01$ ) quando comparado aos com dieta oral. Nutrição parenteral foi mais associada à hipofosfatemia versus nutrição enteral $(p=0,001)$ e nutrição enteral suplementada com parenteral $(p=0,002)$.

CONCLUSÃo: A frequência de pacientes críticos com hipofosfatemia e em risco de SR é alta e esse risco aumenta após o início da TN, especialmente nos desnutridos e naqueles recebendo nutrição parenteral.

PALAVRAS-CHAVE: Cuidados críticos. Hipofosfatemia. Síndrome de realimentação. Desnutrição. Terapia nutricional.

\section{REFERENCES}

1. Marinella MA. The refeeding syndrome and hypophosphatemia. Nutr Rev. 2003;61(9):320-3

2. Araujo Castro M, Vázquez Martínez $C$. The refeeding syndrome. Importance of phosphorus. Med Clin (Barc). 2018;150(12):472-8

3. Olthof LE, Koekkoek WACK, van Setten C, Kars ICN, van Blokland D, van Zanten ARH. Impact of caloric intake in critically ill patients with, and without, refeeding syndrome: a retrospective study. Clin Nutr. 2018;37(5):1609-17.

4. Fernández López MT, Gómez Márquez ÁM, Casado Vázquez L, Alonso Urrutia S, Bardasco Alonso ML, Rivero Luis MT, et al. Incidence of hypophosphatemia in not critically ill patients with enteral feeding. Nutr Hosp. 2017;34(4):761-6.

5. Fuentes E, Yeh DD, Quraishi SA, Johnson EA, Kaafarani H, Lee J, et al. Hypophosphatemia in enterally fed patients in the surgical intensive care unit: common but unrelated to timing of initiation or aggressiveness of nutrition delivery. Nutr Clin Pract. 2017;32(2):252-7.

6. Talakoub R, Bahrami M, Honarmand A, Abbasi S, Gerami H. The predicting ability of serum phosphorus to assess the duration of mechanical ventilation in critically ill patients. Adv Biomed Res. 2017;25:6:51.

7. Pourhassan M, Cuvelier I, Gehrke I, Marburger C, Modreker MK, Volkert $D$, et al. Prevalence of risk factors for the refeeding syndrome in older hospitalized patients. J Nutr Health Aging. 2018;22(3):321-7.

8. Doig GS, Simpson F, Heighes PT, Bellomo R, Chesher D, Caterson ID, et al; Refeeding Syndrome Trial Investigators Group. Restricted versus continued standard caloric intake during the management of refeeding syndrome in critically ill adults: a randomised, parallel-group, multicenter, single-blind controlled trial. Lancet Respir Med. 2015;3(12):943-52.
9. Kraaijenbrink BV, Lambers WM, Mathus-Vliegen EM, Siegert CE. Incidence of refeeding syndrome in internal medicine patients. Neth J Med. 2016;74(3):116-21.

10. Crook MA. Refeeding syndrome: problems with definition and management. Nutrition. 2014;30(11-12):1448-55.

11. National Institute for Health and Care Excellence: Clinical Guidelines. Nutrition support for adults: oral nutrition support, enteral tube feeding and parenteral nutrition. London: National Institute for Health and Care Excellence (UK); 2006.

12. Boot R, Koekkoek KWAC, van Zanten ARH. Refeeding syndrome: relevance for the critically ill patient. Curr Opin Crit Care. 2018;24(4):235-40.

13. Zeki S, Culkin A, Gabe SM, Nightingale JM. Refeeding hypophosphataemia is more common in enteral than parenteral feeding in adult in patients. Clin Nutr. 2011;30(3):365-8.

14. van Zanten $A R H$, De Waele E, Wischmeyer PE. Nutrition therapy and critical illness: practical guidance for the ICU, post-ICU, and long-term convalescence phases. Crit Care. 2019;23(1):368.

15. Viana LA, Burgos MG, Silva RA. Refeeding syndrome: clinical and nutritional relevance. Arq Bras Cir Dig. 2012;25(1):56-9.

16. Machado JD, Suen VM, Chueire FB, Marchini JF, Marchini JS. Refeeding syndrome, an undiagnosed and forgotten potentially fatal condition. BMJ Case Rep. 2009;2009. pii: bcr07.2008.0521.

17. Detsky AS, McLaughlin JR, Baker JP, Johnston N, Whittaker S, Mendelson RA, et al. What is subjective global assessment of nutritional status? JPEN | Parenter Enteral Nutr. 1987;11(1):8-13. 
18. Dock-Nascimento DB, Arantes SS, Silva Ir IM, Aguilar-Nascimento JE. A sobrecarga intravenosa de líquidos e sódio pode contribuir para a menor infusão de nutrição enteral em pacientes críticos. Rev Bras Ter Intensiva. 2019;31(2):202-9.

19. Brown KA, Dickerson RN, Morgan LM, Alexander KH, Minard G, Brown $\mathrm{RO}$. A new graduated dosing regimen for phosphorus replacement in patients receiving nutrition support. JPEN J Parenter Enteral Nutr. 2006;30(3):209-14.

20. Skipper A. Refeeding syndrome or refeeding hypophosphatemia: a systematic review of cases. Nutr Clin Pract. 2012;27(1):34-40
21. Koekkoek WAC Van Zanten $A R H$ Is refeeding syndrome relevant for critically ill patients? Curr Opin Clin Nutr Metab Care. 2018;21(2):130-7.

22. Tappy L, Schwarz JM, Schneiter P, Cayeux C, Revelly JP, Fagerquist CK, et al. Effects of isoenergetic glucose-based or lipid-based parenteral nutrition on glucose metabolism, de novo lipogenesis, and respiratory gas exchanges in critically ill patients. Crit Care Med. 1998;26(5):860-7.

23. McClave SA, Weijs PJ. Preservation of autophagy should not direct nutritional therapy. Curr Opin Clin Nutr Metab Care. 2015;18(2):155-61.

24. Ranzani OT, Zampieri FG, Forte DN, Azevedo LC, Park M. C-reactive protein/albumin ratio predicts 90 -day mortality of septic patients. PLoS One. 2013;8(3):e59321. 